\title{
Ovarian Reserve Assessment after Laparoscopic Ovarian Drilling in women with Polycystic Ovary Syndrome
}

\author{
Ahmed M. Abulkassem ${ }^{1 *}$ MSc; Emad M. Abd Ellatif ${ }^{1}$ MD; Abdullah K. Ahmed ${ }^{1}$ MD
}

\author{
*Corresponding Author: \\ Ahmed M. Abulkassem \\ dr_ahmedkassem2013@yahoo.com
}

Received for publication June 15, 2020; Accepted January 3, 2021; Published online January 3, 2021.

\begin{abstract}
Copyright 2020 The Authors published by Al-Azhar University, Faculty of Medicine, Cairo, Egypt. All rights reserved. This an openaccess article distributed under the legal terms, where it is permissible to download and share the work provided it is properly cited. The work cannot be changed in anyway or used commercially.

doi: $10.21608 /$ aimj.2021.32825.1251

${ }^{1}$ Obstetrics and Gynecology Department, Faculty of Medicine,
\end{abstract} Al-Azhar University, Cairo,Egypt.

\begin{abstract}
Background: Polycystic ovary syndrome (PCOS) is a widespread endocrinopathy, which affects 4-8 percent of women during their reproductive age. Oligomenorrhea, amenorrhea and erratic menstrual bleeding are menstrual irregularities frequently seen in PCOS.

Aim of the work: To evaluate the effect of laparoscopic ovarian drilling on ovarian reserve in patients with polycystic ovarian syndrome before and after LOD measured by serum anti-mullerian hormone levels, FSH seconed day from the begning of menstrual cycle, ovarian volume and AFC.

Patients and Methods: This study was conducted with 38 patients who were candidates for laparoscopic ovarian drilling (clomiphene citrate resistant patients) for polycystic ovarian syndrome at Al-Hussein University Hospital. The diagnosis of polycystic ovarian syndrome was developed on the basis of the Rotterdam criterion. Patients with age 1935 years, presence of ovarian pathology detected by transvaginal ultrasound were excluded from the study.

Results: A significant negative correlation was between age and difference between pre- and post-LOD serum AMH. There no significant association between obesity or clinical hyperandrogenism (hirsutism and/or acne vulgaris) and any of the differences between pre- and postLOD values for sonographic or biochemical markers of ovarian reserve. Presence of amenorrhea was significantly associated with higher difference between pre- and post-LOD AFC of the right ovary. The antimullerian hormone, AFC \& Ovarian Volume after LOD decreased significantly $(\mathrm{P}<0.001)$, While the FSH seconed day from the begning of menstrual cycle after LOD increased significantly $(\mathrm{P}<0.001)$.

Conclusion: It could be concluded that PCOS women after LOD these occurs: Anti-mullerian hormone decreased significantly. The FSH seconed day from the begning of menstrual cycle increased significantly. AFC \& Ovarian Volume decreased significantly.
\end{abstract}

Keywords: Laparoscopy; Ovarian; Drilling; Syndrome; Anti-mullerian hormone. Authorship: All authors have a substantial contribution to the article.

\section{INTRODUCTION}

Infertility affects 40 percent of women with PCOS. Around 90-95 \% of women in infertility clinics have PCOS due to anovulatory infertility.$^{16}$ PCOS is known as a complex related to amenorrhea, hirsutism and enlarged polycystic ovaries. . $^{15}$

The diagnosis of polycystic ovary syndrome was based on the recommendations of national institutes of health. The European Society for Human Reproduction and the American Society of Reproductive Medicine (ASRM) proposed new standards of PCOS diagnosis at a Joint Meeting in 2003. The consensus group in Rotterdam reviewed Polycyst Ovarian syndrome diagnostic criteria: two criteria are important for diagnosing PCOS: Oligo and/or anovulation, clinical and biochemical hyperandrogenic syndrome and other cases of the syndrome (congenital adrenal hyperplasia, androgen secretion tumours and Cushing syndrome) and/or polycystic hyperandrogenism (polycystic syndrome). ${ }^{14}$

Although the PCO primary defect is unspecified, treatment is designed to restorate ovulatory cycles to achieve pregnancy, ${ }^{3}$ Stein and Leventhal (1935) were the first known treatment for anovulatory PCOS patients with ovarian wedge resection, which was largely abundant due to the risk of post-surgical adhesions. ${ }^{13}$

Laparoscopic ovarian drilling (L.O.D) surgical therapy may prevent or minimise the need for gonadotropins or may promote their use. ${ }^{5}$

Less trauma and less postoperative adhesion can be carried out. But it can lead to ovarian tissue injury and inducing ovarian reserve reduction due to the amount of tissue extracted during procedures and its associated laparoscopic vastness. 
The ovarian reserve relates to follicle oocyte size , number and efficiency. The ovarian reserve is the ovarian 's reproductive potential showing the multiple follicles. Ovarian reserve and reproductive capability of women are diminished by ageing (Hansen et al., 2008). ${ }^{6}$ Antimuller hormone assessment (AMH) serum level can be used as an ovarian reserve indicator. Serum AMH levels were eliminated during cycle bleeding and the whole cycle has minor changes in intra-cycles.

The current study aimed at assessing the effects of LAP on ovarian reserve in patients with ovarian polycystic syndrome, before and after LOD by FSH seconed day after menstrual cycle begins ovarian volume and AFC with serum anti-mulleric hormone levels.

\section{PATIENTS AND METHODS}

At the Al-Hussein University Hospital Department of Obstetrics and Gynecology, our prospective nested cohort study was conducted. Subjects were recreuited from patients attending gynecology outpatient clinic of $\mathrm{AL}$ hussein university hospital from the first of June 2018 till the first of may 2020. This study involved reproductiveage patients (19-35) with polycystic ovary syndrome (PCOS) that were immune to clomiphene citrate drug therapy.

Sample size was calculated using OpenEpi version 2.3.1. Data from a previous related study revealed that the mean number of antral follicles was $16.5 \pm 1.3$ before ovarian drilling and $14.9 \pm 2.1$ after ovarian drilling, a statistically significant difference $(\mathrm{p}=0.007)$. A minimal sample size of 38 cases was provided by calculation according to these values. Therefore, as minimum of 45 women with a diagnosis of PCOS planned for laparoscopic ovarian drilling to reach at least 38 cases in case of drop out during follw up.

Inclusion criteria include: Patient at reproductive age (1935 years) diagnosed according Rotterdam criteria as ovulatory disturbance, hyper-androgenism and presence $>10$ follicle, Ultrasound examination in 2-9 mm diameter in each ovary. Clomiphene citrate resistant failed to react to up to $150 \mathrm{mg} /$ day of clomiphene citrate for at least three cycles. ${ }^{8}$

Exclusion criteria include: Age $<19$ and $>35$ years. Preexsisting endocrine disease i.e. persistent diabetes mellitus, hyperprolactinemia and hypothyroidism. Previous caesarian section or any previous abdominal surgery. BMI $>40 \mathrm{~kg} / \mathrm{m}^{2}$.

Explained for the patients who participated in the study all the procedure. Written consent from all the patients were taken and told them that they have the rights to refuse or stop the participation in the trails.

All patients had the following: Full history is taken (Gynaecological and Obstetrical). Index of body mass in kilograms/(height) ${ }^{2}$ metres, determined by weight. General examination (including vital signs). Abdominal examination. Gynaecological examination.

Transvaginal ultrasound was done at the second day of cycle before laparoscopic ovarian drilling. PCOS were diagnosed on the basis of Rotterdam criteria; at least the presence of 2 was: oligomenorrhoea or amenorrhoea, which in the past 12 months had 8 or less menstruation. Hyperandrogenism clinical and/or biochemical symptoms exclude other cases of hyperandrogenism (congenital supranational hyperplasia, tumour androgen secretion and Cushing syndromes). Polycystic ultrasound ovaries: an enlarged or regular ovary of more than 10 follicle size (2$9 \mathrm{~mm}$ in diameter) and a thick stroma with several subcortical follicles. Transvaginal ultrasound The Ultrasound Examination was conducted on cycle 2 with a $7.5 \mathrm{MHz}$ transvaginal test under the full magnification of the ovaries. The second dimension was determined; the vaginal probe was rotated to $90^{\circ}$ to obtain the third dimension, following the determination of the longer Median ovarian axis.

Each patient was treated and held in tubes containing clot activator material in five $\mathrm{ml}$ venous blood samples prior to surgery. Till further study, the sample has centrifuged and serum collected and was stored at $-20^{\circ} \mathrm{C}$ in freezer.

Laparoscopic ovarian drilling was done under general anesthesia. A $10 \mathrm{~mm}$ diagnostic laproscope was used, along with $5 \mathrm{~mm}$ second puncture manipulation probe, placed suprapubically in the midline, to evaluate the pelvis after confirming the presence of bilateral polycystic ovaries and tubal patency controlled with methylene blue. Each ovary manipulated by holding its ligament with a traumatic $5 \mathrm{~mm}$ grasping forceps passed through suprapubic $5 \mathrm{~mm}$ trochar., Each ovary has four punchings each with a diameter of $4 \mathrm{~mm}$.

After surgery, the ovarian volume and AFC were assessed by transvaginal ultrasound together with assessment of seum human chorionoic gonadotropin, $\mathrm{FSH}$ and $\mathrm{AMH}$

Transvaginal ultrasound together with hormonal assessment of HCG,FSH and AMH were done in the second day of menustruation after LOD.If menustruation doesn't occur six weeks afterLOD progesterone challenge test was done to induce withdrawal bleeding then ovarian volume and $\mathrm{AFC}$ were assessed by transvaginal ultrasound together with hormonal assessment of seum human chorionoic gonadotropin, FSH and AMH.

Present statistical method: The Microsoft $₫$ Excel $₫ 2010$ and Windows ${ }^{\circledR}$ 15.0 Statistic Social Sciences (SPSS $®$ ) packages were used for statistical analytical research. The range, mean and standard deviations (where parametric), and the range, median and ranges (where nonparametric), should be expressed continuously. Number and percentages of dichotome or categorical data were presented. Repeated measures in the same group will be compared using two way ANOVA (analysis of variance), The Wilcoxon rank test (for continuous non-parametric variables) and the Chi-squared and McNemar (categorical variables) test. The level of significance is set at 0.05 .

\section{RESULTS}

\begin{tabular}{|c|c|}
\hline $\begin{array}{c}\text { Age (Years) } \\
\text { Range } \\
\text { Mean } \pm \text { SD } \\
\end{array}$ & $\begin{array}{c}19-35 \\
24.76 \pm 4.17\end{array}$ \\
\hline $\begin{array}{l}\text { BMI }\left(\mathbf{K g} / \mathbf{m}^{2}\right) \\
\text { Range } \\
\text { Mean } \pm \text { SD }\end{array}$ & $\begin{array}{c}20.4-40 \\
28.48 \pm 4.24\end{array}$ \\
\hline $\begin{array}{c}\text { Type of Infertility } \\
\text { Primary } \\
\text { Secondary } \\
\end{array}$ & $\begin{array}{c}31(81.6 \%) \\
7(18.4 \%)\end{array}$ \\
\hline
\end{tabular}

Table 1: Demographic Data of Included Women.
Obstetrics and Gynecology 
All of the included women had menstrual irregularity, in the form of oligomenorrhea [in 31 $(81.6 \%)$ women] and amenorrhea [in $7(18.4 \%)$ women]. Of the included 38 women, 22 (54.2\%) had clinical features of hyperandrogenism, in the form of hirsutism [in $11(28.9 \%)$ women] and acne vulgaris [in $10(26.3 \%)$ women] (table-2) . Descriptions of ovarian reserve pre-LOD sonographic markers (ovarian volume and anti-follicle count (AFC)) are shown on both sides as shown in (Table-3). Descriptives of pre-LOD biochemical markers of the ovarian reserve (basal serum FSH and AMH) are shown in Table (4).

\begin{tabular}{||c|c||}
\hline $\begin{array}{c}\text { Menstrual Irregularity } \\
\text { Oligomenorrhea }\end{array}$ & $\mathbf{3 1}(\mathbf{8 1 . 6 \% )})$ \\
Amenorrhea & $\mathbf{7 ( 1 8 . 4 \% )}$ \\
\hline $\begin{array}{c}\text { Clinical Hyperandrogenism } \\
\text { Hirsutism }\end{array}$ & $11(28.9 \%)$ \\
Acne Vulgaris & $\mathbf{1 0}(\mathbf{2 6 . 3 \%})$ \\
\hline
\end{tabular}

Table 2: Menstrual Characteristics and Clinical Features of Hyperandrogenism in Included Women.

\begin{tabular}{|c|c|}
\hline $\begin{array}{c}\text { Pre-LOD Right Ovarian Volume } \\
(\mathbf{c m 3})\end{array}$ & $9-14.1$ \\
Range \\
Mean \pm SD & $12.06 \pm$ \\
(cm3) & 1.54 \\
Range & \\
Mean \pm SD & $9-14.1$ \\
Pre-LOD Left Ovarian Volume & $11.8 \pm 1.4$ \\
Pre-LOD Right Ovarian AFC & $12-18$ \\
Mean \pm SD & $14.29 \pm$ \\
Pre-LOD Left Ovarian AFC & 1.89 \\
Range & 14.19 \\
Mean \pm SD & 1.72 \\
\hline \hline
\end{tabular}

Table 3: Pre-LOD Sonographic Markers of Ovarian Reserve in Included Women.

\begin{tabular}{|c|c||}
\hline $\begin{array}{c}\text { Pre-LOD Serum FSH }(\mathrm{mIU} / \mathrm{ml}) \\
\text { Range }\end{array}$ & $3-8.9$ \\
Mean \pm SD & $5.74 \pm 1.68$ \\
\hline Pre-LOD Serum AMH (ng/ml) \\
Range & $5.6-16$ \\
Mean \pm SD & $10.88 \pm 2.43$ \\
\hline
\end{tabular}

Table 4: Pre-LOD Biochemical Markers of Ovarian Reserve in Included Women

Significant reductions were in the ovarian volume and AFC on both sides when post-LOD values were compared to the pre-LOD values (table-5). Serum FSH and serum AMH decreased significantly when post-LOD values were compared to pre-LOD values. (table-6). A significant negative correlation was between age and differences between pre- and postLOD serum AMH. Non significant correlation was between age or BMI and the other differences between pre- and post-LOD sonographic or biochemical markers of ovarian reserve (table-7).

\begin{tabular}{|c|c|c|c|c|}
\hline & $\begin{array}{l}\text { Pre- } \\
\text { LOD }\end{array}$ & $\begin{array}{l}\text { Post- } \\
\text { LOD }\end{array}$ & $\begin{array}{c}\text { MPD } \\
(95 \% \text { CI })\end{array}$ & $\mathbf{P}^{*}$ \\
\hline $\begin{array}{c}\text { Right Ovarian Volume } \\
(\mathrm{cm} 3) \\
\text { Range } \\
\text { Mean } \pm \text { SD }\end{array}$ & $\begin{array}{c}9-14.1 \\
12.06 \pm \\
1.54\end{array}$ & $\begin{array}{c}6.5- \\
11.8 \\
8.56 \pm \\
1.45\end{array}$ & $\begin{array}{c}3.48 \\
(3.11 \text { to } \\
3.86)\end{array}$ & $\begin{array}{c}<0.001 \\
\mathrm{HS}\end{array}$ \\
\hline $\begin{array}{c}\begin{array}{c}\text { Left Ovarian Volume } \\
(\mathrm{cm} 3) \\
\text { Range } \\
\text { Mean } \pm \text { SD }\end{array} \\
\end{array}$ & $\begin{array}{c}9-14.1 \\
11.8 \pm \\
1.4\end{array}$ & $\begin{array}{c}6.50- \\
11.6 \\
8.33 \pm \\
1.43 \\
\end{array}$ & $\begin{array}{c}3.45 \\
(3.10 \text { to } \\
3.81)\end{array}$ & $\begin{array}{c}<0.001 \\
\mathrm{HS}\end{array}$ \\
\hline $\begin{array}{l}\text { Right Ovarian AFC } \\
\text { Range } \\
\text { Mean } \pm \text { SD } \\
\end{array}$ & $\begin{array}{c}12-18 \\
14.29 \pm \\
1.89 \\
\end{array}$ & $\begin{array}{c}6-11 \\
8.31 \pm \\
1.59 \\
\end{array}$ & $\begin{array}{c}5.97 \\
(5.61 \text { to } \\
6.32) \\
\end{array}$ & $\begin{array}{c}<0.001 \\
\mathrm{HS}\end{array}$ \\
\hline $\begin{array}{c}\text { Left Ovarian } \\
\text { AFC } \\
\text { Range } \\
\text { Mean } \pm \text { SD }\end{array}$ & $\begin{array}{c}11-19 \\
14.53 \pm \\
1.72\end{array}$ & $\begin{array}{c}6-11 \\
8.28 \pm \\
1.43\end{array}$ & $\begin{array}{c}6.23 \\
(5.78 \text { to } \\
6.69)\end{array}$ & $\begin{array}{c}<0.001 \\
\mathrm{HS}\end{array}$ \\
\hline
\end{tabular}

Table 5: Paired Differences between Pre- and PostLOD Sonographic Markers of Ovarian Reserve in Included Women

\begin{tabular}{|c|c|c|c|c|}
\hline & Pre-LOD & $\begin{array}{l}\text { Post- } \\
\text { LOD }\end{array}$ & $\begin{array}{c}\text { MPD } \\
(95 \% \text { CI })\end{array}$ & $\mathbf{P}^{*}$ \\
\hline $\begin{array}{c}\text { Serum FSH } \\
(\mathrm{mIU} / \mathrm{ml}) \\
\text { Range } \\
\text { Mean } \pm \text { SD }\end{array}$ & $\begin{array}{c}3-8.9 \\
5.74 \pm \\
1.68\end{array}$ & $\begin{array}{c}3.5- \\
12.1 \\
8.70 \pm \\
2.21\end{array}$ & $\begin{array}{c}-2.95 \\
(-3.30 \text { to }- \\
2.61)\end{array}$ & $\begin{array}{c}<0.001 \\
\text { HS }\end{array}$ \\
\hline $\begin{array}{c}\text { Serum AMH } \\
(\text { ng/ml }) \\
\text { Range } \\
\text { Mean } \pm \text { SD }\end{array}$ & $\begin{array}{c}5.6-16 \\
10.88 \pm \\
2.43\end{array}$ & $\begin{array}{c}2-10.6 \\
4.42 \pm \\
2.54\end{array}$ & $\begin{array}{c}6.45 \\
(5.97 \text { to } \\
6.93)\end{array}$ & $\begin{array}{c}<0.001 \\
\text { HS }\end{array}$ \\
\hline
\end{tabular}

Table 6: Paired Differences between Pre- and PostLOD Biochemical Markers of Ovarian Reserve in Included Women

\begin{tabular}{|c|c|c|c|}
\hline & & 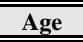 & 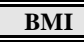 \\
\hline \multirow{3}{*}{$\begin{array}{c}\text { Difference between Pre- } \\
\text { and Post-LOD Right } \\
\text { Ovarian Volume }\end{array}$} & rs & 0.004 & -0.219 \\
\hline & $\mathrm{p}$ & 0.980 & 0.186 \\
\hline & & NS & NS \\
\hline \multirow{3}{*}{$\begin{array}{l}\text { Difference between Pre- } \\
\text { and Post-LOD Left } \\
\text { Ovarian Volume }\end{array}$} & $\mathrm{rs}$ & 0.059 & -0.277 \\
\hline & $\mathrm{p}$ & 0.726 & 0.092 \\
\hline & & NS & NS \\
\hline \multirow{3}{*}{$\begin{array}{c}\text { Difference between Pre- } \\
\text { and Post-LOD Right } \\
\text { Ovarian AFC }\end{array}$} & rs & 0.151 & 0.125 \\
\hline & $\mathrm{p}$ & 0.364 & 0.456 \\
\hline & & NS & NS \\
\hline \multirow{3}{*}{$\begin{array}{c}\text { Difference between Pre- } \\
\text { and Post-LOD Left } \\
\text { Ovarian AFC }\end{array}$} & rs & -0.151 & -0.210 \\
\hline & $\mathrm{p}$ & 0.364 & 0.206 \\
\hline & & NS & NS \\
\hline \multirow{3}{*}{$\begin{array}{l}\text { Difference between Pre- } \\
\text { and Post-LOD Serum FSH }\end{array}$} & rs & -0.197 & -0.215 \\
\hline & $\mathrm{p}$ & 0.237 & 0.194 \\
\hline & & NS & NS \\
\hline \multirow{3}{*}{$\begin{array}{c}\text { Difference between Pre- } \\
\text { and Post-LOD Serum } \\
\text { AMH }\end{array}$} & rs & -0.452 & 0.025 \\
\hline & $\mathrm{p}$ & 0.004 & 0.881 \\
\hline & & $\mathrm{S}$ & NS \\
\hline
\end{tabular}

Table 7: Correlation between Differences between Pre- and Post-LOD Sonographic and Biochemical Markers of Ovarian Reserve, and Each of Age and BMI

There was no significant correlation between obesity or clinical hyperandrogenism (hirsutism and/or acne vulgaris) and any of the differences between pre- and post-LOD values for sonographic or biochemical markers of ovarian reserve. Presence of amenorrhea was significantly associated with higher difference between pre- and post-LOD AFC of the right ovary (table-8). 


\begin{tabular}{|c|c|c|c|c|c|c|}
\hline & \multicolumn{2}{|c|}{ Obesity } & \multicolumn{2}{|c|}{ Amenorrhea } & \multicolumn{2}{|c|}{$\begin{array}{c}\text { Clinical } \\
\text { Hyper- } \\
\text { androgenism }\end{array}$} \\
\hline & $\begin{array}{l}\text { MD } \\
(\mathbf{9 5 \%} \\
\text { CI }) \\
\end{array}$ & $\mathbf{P}$ & $\begin{array}{c}\text { MD } \\
(\mathbf{9 5 \%} \\
\text { CI }) \\
\end{array}$ & $\mathbf{P}$ & \begin{tabular}{|c|} 
MD \\
$(95 \%$ \\
CI $)$ \\
\end{tabular} & $\mathbf{P}$ \\
\hline $\begin{array}{c}\text { Difference between } \\
\text { Pre- and Post-LOD } \\
\text { Right Ovarian Volume }\end{array}$ & $\begin{array}{c}-0.05 \\
(-0.91 \\
\text { to } \\
0.81) \\
\end{array}$ & $\begin{array}{c}0.907 \\
\text { NS }\end{array}$ & $\begin{array}{c}-0.29 \\
(-1.27 \\
\text { to } \\
0.67) \\
\end{array}$ & $\begin{array}{c}0.537 \\
\text { NS }\end{array}$ & $\begin{array}{c}-0.20 \\
(-0.96 \\
\text { to } 0.55) \\
\end{array}$ & $\begin{array}{c}\mathbf{0 . 5 8 8} \\
\text { NS }\end{array}$ \\
\hline $\begin{array}{l}\text { Difference between } \\
\text { Pre- and Post-LOD } \\
\text { Left Ovarian Volume }\end{array}$ & $\begin{array}{c}-0.20 \\
(1.01 \\
\text { to } \\
0.60) \\
\end{array}$ & $\begin{array}{c}0.618 \\
\text { NS }\end{array}$ & $\begin{array}{c}-0.36 \\
(-1.28 \\
\text { to } \\
0.54) \\
\end{array}$ & $\begin{array}{c}0.419 \\
\text { NS }\end{array}$ & $\begin{array}{c}-0.33 \\
(-1.04 \\
\text { to } 0.37) \\
\end{array}$ & $\begin{array}{c}0.350 \\
\text { NS }\end{array}$ \\
\hline $\begin{array}{l}\text { Difference between } \\
\text { Pre- and Post-LOD } \\
\text { Right Ovarian AFC }\end{array}$ & $\begin{array}{c}0.17 \\
(-0.64 \\
\text { to } \\
0.98) \\
\end{array}$ & $\begin{array}{c}0.672 \\
\text { NS }\end{array}$ & $\begin{array}{c}0.90 \\
(0.03 \\
\text { to } \\
1.78)\end{array}$ & $\begin{array}{c}0.042 \\
\mathrm{~S}\end{array}$ & $\begin{array}{c}0.05 \\
(-0.66 \\
\text { to } 0.78)\end{array}$ & $\begin{array}{c}0.870 \\
\text { NS }\end{array}$ \\
\hline $\begin{array}{l}\text { Difference between } \\
\text { Pre- and Post-LOD } \\
\text { Left Ovarian AFC }\end{array}$ & $\begin{array}{c}-0.59 \\
(-1.62 \\
\text { to } \\
0.43) \\
\end{array}$ & $\begin{array}{c}0.250 \\
\text { NS }\end{array}$ & $\begin{array}{c}0.05 \\
(-1.13 \\
\text { to } \\
1.25) \\
\end{array}$ & $\begin{array}{c}0.919 \\
\text { NS }\end{array}$ & $\begin{array}{c}-0.21 \\
(-1.13 \\
\text { to } 0.71)\end{array}$ & $\begin{array}{c}0.648 \\
\text { NS }\end{array}$ \\
\hline $\begin{array}{c}\text { Difference between } \\
\text { Pre- and Post-LOD } \\
\text { Serum FSH }\end{array}$ & $\begin{array}{c}-0.58 \\
(-1.36 \\
\text { to } \\
0.18) \\
\end{array}$ & $\begin{array}{c}0.130 \\
\text { NS }\end{array}$ & $\begin{array}{c}-0.79 \\
(-1.65 \\
\text { to } \\
0.07) \\
\end{array}$ & $\begin{array}{c}0.072 \\
\text { NS }\end{array}$ & $\begin{array}{c}0.03 \\
(-0.67 \\
\text { to } 0.73)\end{array}$ & $\begin{array}{c}0.926 \\
\text { NS }\end{array}$ \\
\hline $\begin{array}{l}\text { Difference between } \\
\text { Pre- and Post-LOD } \\
\text { Serum AMH }\end{array}$ & $\begin{array}{c}-0.67 \\
(-1.76 \\
\text { to } \\
0.41)\end{array}$ & $\begin{array}{c}0.217 \\
\text { NS }\end{array}$ & $\begin{array}{c}-0.86 \\
(-2.09 \\
\text { to } \\
0.36)\end{array}$ & $\begin{array}{c}0.163 \\
\text { NS }\end{array}$ & $\begin{array}{c}0.62 \\
(-0.33 \\
\text { to } 1.58) \\
\end{array}$ & $\begin{array}{c}0.194 \\
\text { NS }\end{array}$ \\
\hline
\end{tabular}

Table 8: Association between Clinical Features and Differences between Pre- and Post-LOD Sonographic and Biochemical Markers of Ovarian Reserve in Included Women.

\section{DISCUSSION}

In the current study, the effect of laparoscopic ovarian drilling on ovarian reserve was examined in patients with polycystic ovarian syndrome as assessed by ovarian volume and antral follicle count by trans-vaginal ultrasound, serum follicular stimulating hormone and serum anti-mullerian hormone levels before and after laproscopic ovarian drilling on the second day of the menstrual cycle.

Significant decrease was in serum AMH in the current study when post-LOD values were compared to pre-LOD values that were not compatible with the study of Sawaek et al . (2007), who investigated the ovarian reserve of women undergoing laparoscopic ovarian drilling with polycystic ovary syndrome. There were 21 PCOS women subject to LODs. The levels of AMH seemed to be lower than in groups of PCOS $(5.99 \pm 3.36 \mathrm{ng} / \mathrm{mli})$ in the LOD $(4.60 \pm 3.16$ $\mathrm{ng} / \mathrm{ml}$ ) but were not statistically important.

In the LOD, the ovarian supply measured by hormonal concentration and sonography appears to be less than in the PCOS community. The PCOS women had considerably larger ovarian reserves both with LOD and without LOD than the normal agematched check menstruations. The difference was that the inclusion criteria for this current study included patients with $\mathrm{CC}$ resistance.

The findings of the current study are consistent with the study of Amer and Ladger (2009) which studied the significance of Antimillary Hormone Measurement in Women with LAB. The median pre-treatment plasma AMH concentrations were $6.1(1.0-21.0)$ and 5.7 (1.3$9.5) \mathrm{ng} / \mathrm{ml}$ in women with LOD and clomiphene citrate therapy. In comparison with non-responders[9.0 (6.117.1) $\mathrm{ng} / \mathrm{ml}]$, pre-operative AMH [5.6 (1.0-21.0) ng / $\mathrm{ml}$ ] was also marginally lower in the women who ovulated after LOD $(n=24)$ The use of recipients characteristic curve tests, AMH was a useful predictor of no ovulation after LODs with region below 0.804 (P $=0.025)$. They concluded that the amount of AMH pretreatment circulating appears to be a good predictor of ovarian LOD reactions. The reduction in AMH to $65 \%$ of preoperative levels may result from the LOD destruction of small follicles that are the source of $\mathrm{AMH}$. If this is true, a decrease in AMH due to LOD could lead to an increase in follicular response from the start of the menstrual cycle to circulating $\mathrm{FHH}$ on the second day, thus making it easier for the dominant follicle to increase growth and selection. Alliterally, post-operative declines in AMH can be the result of atresia of many small follicles as part of normal follicular growth leading to ovulation. If it is real, it may be the result of ovulation according to LOD instead of the cause of the observed decrease in AMH. The hypothesis that the decrease of AMH is a cause of ovulation was supported by the finding that, on the second day after the menstructural cycle the FSH level did not increase after LOD, suggesting that on the second day after the start of the menstrual cycle the ovulation resulted in the increased sensitivity of the follicles to FSH.

The current study agrees with, ${ }^{2}$ in which he showed a significant decrease in serum AMH levels and AFC was observed after LOD in the 1st, 3rd and 6th cycles..

In the present study the ovarian reserve was examined in accordance with. 8 after clomiphene citrate treatment. Unilateral LOD \& bilateral LOD \& showed that ovarian reserve was significantly reduced only after bilateral LOD . The decrease of AMH not due to change in the ovarian reserve after LOD but patient's status returned back to normal.

Results of the present study found that AMH and the follicle numbers per ovary and ovarian volume had a positive significant correlation, and this was in line with. $^{1}$ results. These results show that serum AMH levels can be used to indicate the follicle number..Thus AMH correctly said to reflect the ovarian reseve.

The present study in accordance with the study of.$^{4}$ which showed a positive correlation between basal serum AMH and antral follicle number. $(r=0.685$, $\mathrm{p}<0.05)$.

The results of the present study were consistent with, ${ }^{11,10.12}$ and their findings were related to the amount of antral follicles obtained in normal cycling women and in PCOS women levels of serum AMH. The two-three fold increase of the growth of follicula represented an increase of two-three in serum levels of AMH.

\section{CONCLUSION}

It could be concluded that PCOS women after LOD these occurs: Anti-mullerian hormone decreased significantly. The FSH second day from the beging of menstrual cycle increased significantly. AFC \& Ovarian Volume decreased significantly.
Obstetrics and Gynecology 


\section{REFERENCES}

1. Anderson RA: What does Anti-mullerian hormone tell you about ovarian function? Clincal Endocrinology, 2012; 77: 652-5.

2. Elmashad A: Impact of laproscopic ovarian drilling on Anti-mullerian hormone levels and ovarian stromal blood flow using three dimentional power Doppler in women with anovulatory PCOS. Fertil Steril. 2011; 95(7):2342-6.

3. Farquhar C, Lilford RJ, Marjöribanks $\mathrm{J}$ and Vandekerckhove P: Laparoscopic drilling by dithermy or laser for ovulation induction in anovulatory polycystic ovary syndrome. Cochrane Database Syst Rev., 2007; 3:CDOO1 122.

4. Farzadi L, Nouri M, Ghojazadeh M, Mohiti M and Aghadaroid E: Evaiuation of ovarian reserve after laproscopic surgery in patients with PCOS. BioImpact, 2012; 2 (3): 167-70.

5. Gurgan $\mathrm{T}$, Urman B, Aksu $\mathrm{T}$, Yaraly $\mathrm{H}$, Develioglu $\mathrm{O}$ and Kisnisci $\mathrm{H}$ : The effect of short interval laparoscopic lysis of adhesion on pregnancy rate following $\mathrm{Nd}$ :YAG laser photocoagulation of polycystic ovaries. Obstet Gynaeco, 1992 ;80:45-7.

6. Hansen KR, Knowlton NS, Thyer AC, Charleston JS, Soules MR and Klein NA (): A new model of reproductive aging: the decline in ovarian non-growing follicle number from birth to menopause. Hum Repord. 2008; 23: 699-08.

7. Iwase A, Hirokawa W, Goto M, Takikawa S, Nagatomo $\mathrm{Y}$, Nakahara $\mathrm{T}$, Manabe $\mathrm{S}$ and Kikkawa F (): Serum antimullerian hormone level is a useful marker for evaluating the impact of laparoscopic cystectomy on ovarian reserve. Fertil Steril. 2010; 94(7):2846-9.

8. Kandil $M$ and Selim $M$ : Hormonal and sonographic assessment of ovarian reserve before and after laparoscopic ovarian drilling in polycystic ovary syndrome. BJOG, 2005; 112:1427-30.
9. Kaya H, Sezik M and Ozkaya O : Evaluation of new surgical approach for the treatment of clomiphere citrate resistant infertility in polycystic ovary syndrome: Laparoscopic ovarin multi-needle intervention. J Minim Invasive Gynaecol. 2005; 12:355-8.

10. Laven JS, Mulders AG, Visser JA, Themmen AP, de Jong FH and Fauser BC : Anti-Mullerian hormone serum concentrations in normoovulatory and anovulatory women of reproductive age. Journal of Clinical Endocrinology and Metabolism. 2004; 89: 318-23.

11. Panchal S and Nagori C : Comparison of Antimullerian hormone \&Antral follicle count for assessment of ovarian reserve. Jornal of Human Reproductive. 2012; 5(3):274-8.

12. Pigny P, Merlen E, Robert Y, Cortet-Rudelli C, Decanter C and Jonard S and Dewailly D : Elevated serum level of anti-mullerian hormone in patients with polycystic ovary syndrome: relationship to the ovarian follicle excess and to the follicular arrest. Journal of Clinical Endocrinology and Metabolism. 2003;88:5957-2.

13. Portuondo JA, Meichor JC, Neyro JL and Alergre A : Periovarian adhesions following ovarian wedge resection or laparoscopic biopsy. Endoscopy. 1984; 16:143-5.

14. Society for Human Reproduction (ESHRE) and the American Society of Reproductive Medicine (ASRM) (2003); Diagnosis of polycystic ovary syndrome: from NIH criteria to ESHRE-ASRM guidelines. Minerva Ginecol., 56(1):1-6.

15. Stein IF and Leventhal ML : Ammenorrhea associated with bilateral polycystic ovaries. Am. $J$. Obstet. Gynaecol. 1935; 29:181-91.

16. Teede H, Deeks A and Moran L : PCOS: A complex condition with psychological, reproductive \& metabolic manifestations that impacts on health across the life span $B M C$ Med. 2010; $8: 41$. 